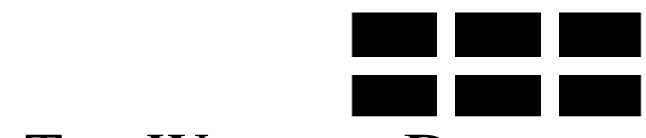

THE WILLIAM DAVIDSON INSTITUTE AT THE UNIVERSITY OF MICHIGAN BUSINESS SCHOOL

\title{
Governing for Genuine Profit
}

\author{
By: Michael J. O'Hara
}

William Davidson Working Paper Number 533

January 2003 


\title{
GOVERNING FOR GENUINE PROFIT
}

\author{
presented to the \\ Corporate Governance and Sustainable Peace Conference \\ hosted by the \\ William Davidson Institute \\ University of Michigan Business School \\ November 2002 \\ by \\ Professor Michael J. O'Hara, J.D., Ph.D. \\ Finance, Banking, \& Law Department \\ College of Business Administration \\ University of Nebraska at Omaha \\ Omaha NE 68182 \\ mohara@mail.UNOmaha.edu \\ (402) 554 - 2823 voice fax (402) $554-2680$
}

\begin{abstract}
:
Business corporations seek profit. That is, after subtracting cost, they maximize net revenue. Spillovers (both costs and benefits) involve trade-offs governing boards should make. Spillovers, especially when coupled with clumsy applications of discounted present value, distort a business' perception of profit. Today, businesses are buffeted by the old risks of recession and the new risks of terrorism. If modern society is to survive, then the seeds of terrorism and their fruit of tremendous loss must be contained. Accordingly, governing boards must propel businesses towards a paradigm of genuine profit. Governing boards must insist that their businesses prospect for positive feedback loops and implement a sustainable profit stream. In short, governing boards must insist that business be entrepreneurial.
\end{abstract}

\section{Keywords:}

Uncertainty, Corporate Governance, Corporate Law, Managerial Discretion, Social Responsibility

JEL Codes:

D81, G34, K22, L21, M14 


\section{GOVERNING FOR GENUINE PROFIT}

\section{INTRODUCTION}

What is the purpose of a business corporation? Since there are many forms of business, that question can have many answers. It is axiomatic in law and economics that a for-profit business exists to maximize profit. For publicly traded firms, profit maximization is rephrased as maximizing shareholder wealth since the discounted present value of all future profit streams equals current shareholder wealth.

Narrowly defined, the goal of shareholder wealth maximization can generate business decisions that are fundamentally flawed. Both critics and corporate mangers lament that corporate governance today is too focused on the next fiscal quarter rather than the long run. An "efficient" market, when populated by day traders who do own shares at neither the start of the day nor at the end of day, further compounds the tendency for myopic management.

This paper will not challenge the shareholder wealth maximization goal. Instead, this paper will insist on it. All too often, the shareholder wealth maximization goal is praised in name and ignored in practice. The decisions of business corporations are decisions requiring tradeoffs. All tradeoffs are complex and tinged with uncertainty. Accordingly, the scope of governance discretion must be broad. In practice rather than in theory, all too often the shareholder wealth maximization goal is ignored. Agents of the principal too narrowly define value streams (when it suits the agent's preference) and both agent's and the market misapply discounting to present values. 
More fully defining the net that is the business' profit and accurately applying the concept of discounted present value will orient a firm towards sustainability. That sustainable orientation fosters peace.

\section{SEEKING PROFIT}

Business corporations are legal persons. Business corporations exist because society wishes to encourage business investment. Society encourages shareholders to place their wealth at risk. The encouragement society offers is liability limited to that investment. Each natural person can tolerate only so much risk. Limited liability allows each investor to place at risk only that fraction of their wealth that can be tolerated. Limited liability allows additional natural persons to invest as well as increases the total pool of available wealth for business formation. Business corporations exist to serve society and society bears the cost of limited liability. Corporations that foster sustainable peace serve society well, and those that defeat peace do not.

The corporation's Board of Directors and the Officers are fiduciaries. They are agents for a principal. Their primary fiduciary duty is to husband their shareholders' investment. The fiduciary duty is to pursue shareholder wealth maximization. The maximization to be pursued is to be long-run, not short-run, shareholder wealth maximization.

Business corporations seek profit, which is total revenue minus total cost. That is, after subtracting cost, they maximize net revenue. More narrowly defined, the corporation maximizes net revenues that are internal to the corporation. Accounting tracks transactional values that go through the corporation. Corporations tend to ignore values that are not internalized by the corporation. 
Values not internalized by the market system are known as externalities or spillovers. All market transactions involve spillovers of varying magnitudes and durability. A market failure is said to exist when a spillover's magnitude becomes so large, durable, and/or predictable that the spillover materially distorts the market's efficiency. For example, education is subsidized because of substantial spillover benefits and pollution is regulated because of substantial spillover costs. The very existence of the firm is a tribute to market failures. The firm exists because the firm is able to assemble the transactions more efficiently than the market by internalizing otherwise external values.

Profit is a net, but net of what? Governing boards and management must choose which spillovers (both costs and benefits) to internalize. They must make trade-offs. A creative executive compensation package is a bundle of values, both internal and external to the firm. The governing board should be no less creative in pursuing sustainable peace.

\section{BIASES OF BUSINESS}

Business is biased towards revenue. Often, this bias is appropriate because a sustainable firm must capture value. Capturing cost tends to be far easier than capturing revenue. However, the true goal is wealth, not revenue.

Business is biased against cost. This anti-cost bias is greatest against internal costs. In fact, external costs are all too often ignored or, worse, are the deliberate consequence of governance. A firm can create the false appearance of increasing profit by externalizing costs. Society, however, sees no profit. Such false profits defeat society's expectations when creating corporations. 
Business corporations have another bias: today is preferred over tomorrow. Managers of risk soon learn that the future is unpredictable and that a bird in the hand is worth more than one in the bush. The precise value of "now" is calculated using discounted present value. However, all too often business distorts that calculation and, in effect, eats its seed corn.

Business focuses upon cash profit in the form of net revenue. That is, business focus on out-of-pocket total revenue minus out-of-pocket total cost. This cash profit is but one measure of value and of wealth. Cash profit fails to track spillovers costs and spillover benefits. Governing boards should govern with an eye on these spillovers so that the board can select the best set of trade-offs for maximization of the shareholders' wealth.

Markets transactions are transactions between participants who are both willing and able. If a participant is either unwilling (e.g., theft) or is unable (e.g., poor) to participate, then the market neither sees nor registers that transaction. Such involuntary transactions generate spillovers or externalities. Cash profits based on substantial spillovers are false profits.

At its essence, board oversight is prioritization in the long run. Prioritization is choosing between options. This choosing requires the acceptance of trade offs. The realm of management is similar in that management also prioritizes and accepts trade offs. However, the realm of management is the short run while the realm of the board is the long run.

The business bias against tomorrow is greatest in management. The board's governance should counter act this management bias. Additionally, as certainty diminishes the role of the board increases. Certainty is diminished by difficult to 
quantify externalities. Also, the magnitude of spillovers often is greatest in the future, the realm of board governance. Spillovers, especially when coupled with clumsy applications of discounted present value, can create a false perception of profit.

Accordingly, cash profit can be a gross misstatement of the firm's value generation. Since the board's governance duty is to maximize shareholder wealth, governance includes choosing which external values to internalize.

\section{VALUE OF A DOLLAR TODAY}

A dollar tomorrow is worth less than a dollar today. For example, when is $\$ 1,000,000$ tomorrow only worth $\$ 1$ today? ${ }^{1}$ At a $20 \%$ interest rate $\$ 1,000,000$ in 70 years is worth but $\$ 1$ today; at $10 \%$, it's 140 years; at $5 \%$, it's 280 years.

$1 \quad$ The text will use rounded numbers. A quick calculation is based on the Rule of 70 and a rounded doubling. The Rule of 70 is an approximation of how many time periods are required to double (if earning interest) or to halve (if paying interest) a dollar value over time. In the Rule of 70 the number 70 is divided by the interest rate stated as an integer. For example, assume annual interest of $7 \%$ per year, then 70 divided by 7 yields 10 periods needed to halve or double a value. Next, note that if $\$ 1$ is doubled successively 20 times the result is $\$ 1,048,576$. Accordingly, the Rule of 70 and 20 doublings indicates that at $7 \%$ interest earned, $\$ 1$ now is worth approximately $\$ 1,000,000$ in 200 years.

The Rule of 70 is an approximation. The accuracy of the approximation depends on the level of the interest rate. The fields of biology and economics, which tend to focus on growth rates in the range between $3 \%$ and $5 \%$, tend to use the Rule of 70 . In contrast, the field of finance, which tends to focus on rate in the range between $6 \%$ and $8 \%$, tend to use the Rule of 72 . 
The required rate of return reflects a variety of risks, such as inflation and business failure. Venture capitalists face some of the greatest risks and routinely strive for a rate of return equaling $100 \%$. In effect, $\$ 1,000,000$ a mere 14 years in the future is only worth $\$ 1$ today. In stark contrast, the Iroquois ${ }^{2}$ recommended management decisions that would serve well the seventh generation. Assuming, as Thomas Jefferson did that a generation is 19 years, then the Iroquois recommend management decisions that valued a million dollars in 133 years as worth one dollar today (almost $7 \%$ ). If one recognizes that in the industrialized world of the $21 \mathrm{st}$ century, a generation may now be more like 30 years, then managing for the seventh generation would require a focus of 210 years (or about a $11 \%$ rate of return).

The key question is: "Will that \$1 be dedicated today for tomorrow's use?". If that $\$ 1$ is not dedicated today, then tomorrow most likely will be hard pressed to pay the piper.

\section{OLD AND NEW: RISKS AND MANAGEMENT}

Today, businesses are buffeted by the old risks of recession and the new risks of terrorism. These demands on business reduce the likelihood business will fund the needs of the future created by the decisions of today. The typical management of old

2 The Iroquois are a confederation of six Native American nations (not a "tribe"). The six are Mohawks, Oneidas, Onondagas, Cayugas, Senecas, and Tuscaroras. In the American Revolution the confederacy split. Some supported the patriots, and others supported the British. They never really had an "empire" in the European sense of occupied territory. They had network of alliances. The U.S. system of government draws some inspiration from the Iroquois system. Donald A. Grinde, Jr., and Bruce E. Johansen, Exemplar of Liberty: Native America and the Evolution of Democracy. Los Angeles: UCLA American Indian Studies Center, 1991. http://www.unomaha.edu/Uno/nams/brucenasbio.htm The Iroquois believe that all important decisions (not just management) should be made with the seventh generation in mind. This is a way of saying that planning should be done in the interests of generations yet unborn, e.g. long-range. These themes are discussed in a profile of Iroquois faithkeeper Oren Lyons in Bruce E. Johansen, Shapers of the Great Debate on Native Americans: Land, Spirit, and Power. Westport, CT: Greenwood Press, 2000. http://www.unomaha.edu/Uno/nams/brucenasbio.htm 
risks focuses on minimizing costs located internally, in part, by ignoring the magnitude of costs located externally. This does not bode well for the future. New management of new risks needs to strive to avoid the tragedy of the commons as well as seek out more synchronicities.

The tragedy of the commons is an unintentional over consumption of a shared resource. The tragedy of the commons results when many individual users each consume at an individual level that is far less than the sustainable level for the shared resource; however, the aggregation of these many individual uses exceeds the sustainable level. In the tragedy of the commons the shared resource degrades and ultimately is destroyed.

Peace reduces business risk and increases profit. Thus, for business, peace is a shared resource. If business does not protect this shared resource, then the tragedy of the commons is the likely result. It is profitable for business to foster peace.

Synchronicity is the essence of business. Profit is a surplus extracted from transactions embedded in multiple, interrelated processes. Timing is critical to profit. The reason the firm exists is the firm better synchronizes some transactions than the market. Timing also is critical to peace. Business needs to foster peace as one of the multiple, interrelated processes that generate the profit upon which businesses live.

Business management and board governance need to seek out and prosper via synchronicity. Management and governance focus on different processes and different synchronicities. Governance has more of an eye on the distant future, thus governance must anticipate more. Governance fails when governance mimics the myopic focus of management. Governance needs a greater anticipation, especially focused on a search for externalities to internalize. Not all externalities should be 
internalized as part of governance's synchronicity. The firm has a small span of control compared with the invisible hand. At its core, however, governance will find synchronicity means that it is profitable for me to be my brother's keeper.

How can increasing internal costs be profitable? That is easy to answer. The alternative is far more costly. If modern society is to survive, then the seeds of terrorism and their fruit of tremendous loss must be contained.

\section{RISK CAN NOT BE ZERO}

Risk can not be zero. This is well understood by managers and boards alike. Also well understood is that the firm can not be all things to all people: the firm must focus on its core competencies. Risk --in the context of terrorism-- threatens the very existence of the firm, especially its long run existence. Governance duties necessarily include addressing such a large risk beyond the time focus of management.

Since risk can not be zero, containment is the maximum feasible success. Unfortunately, from the perspective of business success, contained terrorism might be an utter failure. The maximum feasible consequences of terrorism can extinguish the current world order of global capitalism. Many international firms would be forced to shatter and disintegrate if world markets did not exist. Like any organism deprived of its habitat, extinction would soon follow.

Each organism has a limited ability both to bear and to spread losses. A firm or a market can tolerate a one-time loss of some limited, absolute magnitude. Beyond that limit, the firm can not bend, it breaks. Also, just because the firm can absorb the one time loss, that alone does not mean the firm can survive. In addition to absorbing the one-time loss, the firm must be able to spread the cost across its customer base without making its products too expensive for the customer base. It is true that global 
firms are more resilient than Mom-and-Pop stores, but each has its limits. The maximum feasible consequences of terrorism can exceed even a global firm's ability to bear and spread losses.

The risk that terrorism presents to society and to business is great and is shared. Because the risk of terrorism is great, because it is shared, because it lurks in the future beyond the realm of management and in the realm of governance, there is an increase in the risk of the tragedy of the commons. The probability of shirking of responsibility is greater. Firms, their boards, and their managers are likely to claim it is not their duty and it is not profitable for them to be their brother's keeper. Nothing could be farther from the truth.

\section{SEEDS AND FRUIT}

The seeds of terrorism are in our human condition. Terrorism as a military and as a political tool is fostered by a few conditions. Terrorism is an attractive military and political tool because it is highly leveraged. Businesses can appreciate the magnification of market presence and force via leveraging. Leveraging empowers a terrorist to use relatively few resources to cause great losses. Terrorism is attractive when there is a minimal price of life, in the eyes of the terrorist, both for the terrorist and the enemy. Life appears less valuable when global capitalism spawns grinding poverty juxtaposed with abundance, when illiteracy and oppression are the norm, and especially when ideological intensity (e.g., perversion of religion) washes over the suffering masses. These conditions are ripe for the seeds of terrorism. Add to this volatile mixture the chronic temptation of humans to listen to the lesser angels of our nature, and business should expect sustained losses attributable to terrorism. The 
seeds of terrorism will bear the bitter fruit of substantial losses in place of hoped for profits.

The fruits of tremendous loss, primarily, are technological. By technological it is meant the losses primarily alter the feasible combination of inputs. The losses of terrorism, primarily, are not the assets lost, but rather are the losses in subsequent output. The losses can be minor or major.

"Minor" losses would include specific physical assets and (as crass as it may sound) specific human casualties. The loss of any specific asset is minor, regardless of how many specific assets are lost. These losses do not become major merely when many buildings are destroyed or when many people are killed. As humbling as it may be, individual assets and individual humans rarely are critical to total output.

Losses become major when the losses exceed the firm's, the market's, and/or the society's ability to bear and/or to spread the loss. Major losses exist when there are network effects or adverse shifts in the social psychological paradigms.

Often it is said that the whole is greater than the sum of the parts. This is an example of a network effect. Synchronicity generates the network effect. A welltargeted attack generates a negative network effect because a well-targeted attack is leveraged. A well-targeted attack removes a critical input and thus reduces the usefulness of many other inputs. Without electricity of how much use is a computer? Without a surgeon of how much use is an operating room?

Network effects can be restored via substitution of inputs if the humans are willing to work. Accordingly, a far greater loss than network effects is an adverse shift in social psychological paradigms. The social matrix is necessary for any asset to be productive. If the social matrix collapses, then all assets produce less. 
Humans innately fear the unknown. If terrorism can generate mass uncertainty, then terrorism can extinguish trust. Without trust, the social matrix collapses and firms can not earn profit because their own workers will avoid the firm and the market will be empty. If terrorists can replace optimism with fatalism, or if terrorists can replace trust with fear, then a major loss is suffered.

\section{PARADIGM OF GENUINE PROFIT}

Businesses face new risks to the firm and the to the market. These risks are indigenous to the very social fabric within which business acts. If these risks are not managed, then the existence of the market that sustains the firm and the firm itself are in question. Management of these risks is far from a trivial mater. This management task exceeds the resources and influence of any one government, any collection of governments, and/or collection of non-governmental organizations. Businesses must contribute to the management of these new risks. For managing these risks, businesses often are better situated than most, if not all, governments and nongovernmental organizations in terms of social engagement with the local milieu, in terms of resources on site, and in terms of market intelligence.

Accordingly, governing boards must propel businesses towards a paradigm of genuine profit. The days of a myopic focus on cash profit are over. It is a governance duty of a corporate board to take ownership of the project to create the shift towards a paradigm of genuine profit. The focus of management, appropriately, is on the short-run. Genuine profit requires long-run planning and actions that are not the realm of management.

The shift to a paradigm of genuine profit is needed, but it may be irrelevant. A paradigm shift that is too small, too infrequent, and/or too late will not manage the 
risks of terrorism. The scale, scope, and timing of this paradigm shift must be sufficient to alter experiences and expectations on the ground. Anything less will leave so many seeds of terrorism that the likely harvest will exceed businesses' ability to bear and spread the losses.

Is it foolhardy to expect a sufficient shift towards genuine profit? No. The conference hosted by the William Davidson Institute offers hope. That conference helps belie predictions that the speed of diffusion of terrorist technology will render irrelevant the transformation of corporate governance. We reasonably can hope for a better world when change agents are alert and in motion.

The heavy lifting, however, must be done by the governing boards.

Governing boards must insist that their firms prospect for positive feedback loops and implement a sustainable profit stream. This is not a radical proposal since it is the stuff of business to generate surplus from well-managed synchronicities. All business opportunities require prospecting. What must be avoided is a false sense of success from merely grabbing low hanging fruit versus planting and tending the vineyard. Patient and thoughtful husbandry by governing boards will be needed.

Governing boards must challenge their management teams to search for feedback loops that reinforce and foster peace in addition to capturing cash profit. Every feedback loop is an expansive source of causality. The resonance of causality can be positive or negative in consequence. Positive feedback loops, such as those that nurture freedom, offer synchronicities with the core competency of business: generating profit by serving the will of the consumers. Likewise, negative feedback loops, such as those that nurture terrorism, need to be dampened or the future of business will be bleak. 
A corporate focus on genuine profit fosters positive feedback loops and dampens negative feedback loops. A shortsighted pursuit of an episodic profit stream often is falsely profitable. The shortsighted pursuit of an up-front and nonsustainable profit stream is, however, consistent with the biases of business towards revenue, away from cost, and for today over tomorrow. Mere extraction from a market depletes the market and wastes valuable relationship assets established by the corporation. In contrast, sustainable profit streams are genuinely profitable. A corporate engagement that sees and captures a multitude of value streams --not merely the cash profit value stream-- fosters positive feedback loops with the local market and builds sustainable profit streams. The profitability of the firm increases and, at the same time, peace is reinforced and enhanced by sustainability.

\section{RECOMMENDATION}

In short, governing boards must insist that their firm be entrepreneurial. All entrepreneurs engage in risk management as their primary task. When managing risk an entrepreneur fails to act ethically if focused solely on legal liability, especially when a corporation's owners are shielded from legal liability by limited liability. Governing boards should more fully define their firm's responsibility.

Legal and ethical risk management call for intelligence of design and operation. That intelligence is partly measured by the quantity of and quality of the outputs relative to the firm's inputs as well as the firm's cherished values. A firm that internalizes externalities based on manageable synchronicities and thus reaps a sustainable profit stream manifests such intelligence of design and operation. Such a firm also maximizes shareholder wealth. If governing boards do otherwise and continue to maximize shareholder wealth based on the knowledge of the price of 
William Davidson Institute Working Paper 533

everything and the value of nothing, then we will all share in the tragedy of our common loss of, first, peace and second our entire way of life. 


\section{DAVIDSON INSTITUTE WORKING PAPER SERIES - Most Recent Papers}

The entire Working Paper Series may be downloaded free of charge at: www.wdi.bus.umich.edu

CURRENT AS OF $1 / 17 / 03$

\begin{tabular}{|c|c|c|}
\hline Publication & Authors & Date \\
\hline $\begin{array}{l}\text { No. 533: Forthcoming in Vanderbilt Journal of Transnational Law, } \\
\text { "Governing for Genuine Profit" }\end{array}$ & Michael J. O'Hara & Jan. 2003 \\
\hline $\begin{array}{l}\text { No. 532: Forthcoming in Vanderbilt Journal of Transnational Law, } \\
\text { "Adapting Corporate Governance for Sustainable Peace" }\end{array}$ & $\begin{array}{l}\text { Timothy L. Fort and Cindy A. } \\
\text { Schipani }\end{array}$ & Jan. 2003 \\
\hline $\begin{array}{l}\text { No. 531: Forthcoming in Vanderbilt Journal of Transnational Law, } \\
\text { "Groundings of Voice in Employee Rights" }\end{array}$ & Dana Muir & Jan. 2003 \\
\hline $\begin{array}{l}\text { No. 530: Forthcoming in Vanderbilt Journal of Transnational Law, } \\
\text { Gender Voice and Correlations with Peace }\end{array}$ & $\begin{array}{l}\text { Morehead Dworkin and Cindy A. } \\
\text { Schipani }\end{array}$ & Jan. 2003 \\
\hline $\begin{array}{l}\text { No. 529: Forthcoming in Vanderbilt Journal of Transnational Law, } \\
\text { "The Organizational Model for Workplace Security" }\end{array}$ & Dr. Thomas K. Capozzoli & Jan. 2003 \\
\hline $\begin{array}{l}\text { No. 528: Forthcoming in Vanderbilt Journal of Transnational Law, } \\
\text { "Nationbuilding 101: Reductionism in Property, Liberty, and Corporate } \\
\text { Governance" }\end{array}$ & O. Lee Reed & Jan. 2003 \\
\hline $\begin{array}{l}\text { No. 527: Forthcoming in Vanderbilt Journal of Transnational Law, "On } \\
\text { Virtue and Peace: Creating a Workplace Where People Can Flourish" }\end{array}$ & $\begin{array}{l}\text { Caryn L. Beck-Dudley and } \\
\text { Steven H. Hanks }\end{array}$ & Jan. 2003 \\
\hline $\begin{array}{l}\text { No. 526: Forthcoming in Vanderbilt Journal of Transnational Law, } \\
\text { "Novartis and the United Nations Global Compact Initiative" }\end{array}$ & Lee A. Tavis & Dec. 2002 \\
\hline $\begin{array}{l}\text { No. 525: Why Transition Paths Differ: Russian and Chinese Enterprise } \\
\text { Performance Compared }\end{array}$ & Sumon Bhaumik and Saul Estrin & Jan. 2003 \\
\hline $\begin{array}{l}\text { No. 524: Official Regulations and the Shadow Economy: A Labour } \\
\text { Market Approach }\end{array}$ & Maxim Bouev & Dec. 2002 \\
\hline No. 523: Children at Risk: Infant and Child Health in Central Asia & Cynthia Buckley & Jan. 2003 \\
\hline No. 522: Wages and International Rent Sharing in Multinational Firms & $\begin{array}{l}\text { John W. Budd, Jozef Konings and } \\
\text { Matthew J. Slaughter }\end{array}$ & July 2002 \\
\hline $\begin{array}{l}\text { No. 521: Gross Job Flows in Ukraine: Size, Ownership and Trade } \\
\text { Effects }\end{array}$ & $\begin{array}{l}\text { Jozef Konings, Olga Kupets and } \\
\text { Hartmut Lehmann }\end{array}$ & Dec. 2002 \\
\hline $\begin{array}{l}\text { No. 520: Entrepreneurial Networking in China and Russia: Comparative } \\
\text { Analysis and Implications for Western Executives }\end{array}$ & Bat Batjargal & Dec. 2002 \\
\hline $\begin{array}{l}\text { No. 519: Agriculture and Income Distribution in Rural Vietnam under } \\
\text { Economic Reforms: A Tale of Two Regions }\end{array}$ & $\begin{array}{l}\text { Dwayne Benjamin and Loren } \\
\text { Brandt }\end{array}$ & Mar. 2002 \\
\hline $\begin{array}{l}\text { No. 518: Property Rights, Labour Markets, and Efficiency in a } \\
\text { Transition Economy: The Case of Rural China }\end{array}$ & $\begin{array}{l}\text { Dwayne Benjamin and Loren } \\
\text { Brandt }\end{array}$ & Mar. 2002 \\
\hline $\begin{array}{l}\text { No. 517: Bank Discrimination in Transition Economies: Ideology, } \\
\text { Information or Incentives? }\end{array}$ & Loren Brandt and Hongbin $\mathrm{Li}$ & Oct. 2002 \\
\hline $\begin{array}{l}\text { No. 516: Ex-ante Evaluation of Conditional Cash Transfer Programs: } \\
\text { The Case of Bolsa Escola }\end{array}$ & $\begin{array}{l}\text { François Bourguignon, Francisco } \\
\text { H. G. Ferreira and Phillippe G. } \\
\text { Leite }\end{array}$ & Sep. 2002 \\
\hline No. 515: Missed Expectations: The Argentine Convertibility & $\begin{array}{l}\text { Sebastian Galiani, Daniel } \\
\text { Heymann and Mariano Tommasi }\end{array}$ & Nov. 2002 \\
\hline $\begin{array}{l}\text { No. 514: Job Reallocation and Productivity Growth under Alternative } \\
\text { Economic Systems and Policies: Evidence from the Soviet Transition }\end{array}$ & J. David Brown and John S. Earle & Nov. 2002 \\
\hline $\begin{array}{l}\text { No. 513: Cross-Border Trading as a Mechanism for Capital Flight: } \\
\text { ADRs and the Argentine Crisis }\end{array}$ & $\begin{array}{l}\text { Sebastian Auguste, Kathryn M.E. } \\
\text { Dominguez, Herman Kamil and } \\
\text { Linda L. Tesar }\end{array}$ & Nov. 2002 \\
\hline $\begin{array}{l}\text { No. 512: Embracing the Market: Entry into Self-Employment in } \\
\text { Transitional China, } 1978-1996\end{array}$ & Xiaogang Wu & Sep. 2002 \\
\hline $\begin{array}{l}\text { No. 511: Opening the Capital Account of Transition Economies: How } \\
\text { Much and How Fast }\end{array}$ & $\begin{array}{l}\text { Daniel Daianu and Radu } \\
\text { Vranceanu }\end{array}$ & Sep. 2002 \\
\hline $\begin{array}{l}\text { No. 510: Bridging "the Great Divide": Countering Financial Repression } \\
\text { in Transition }\end{array}$ & Patrick Conway & May 2002 \\
\hline $\begin{array}{l}\text { No. 509: Change the Regime - Change the Money: Bulgarian } \\
\text { Banknotes, 1885-2001 }\end{array}$ & Adrian E. Tschoegl & May 2002 \\
\hline $\begin{array}{l}\text { No. 508: Differential Rewards to, and Contributions of, Education in } \\
\text { Urban China's Segmented Labor Markets }\end{array}$ & $\begin{array}{l}\text { Margaret Maurer-Fazio and Ngan } \\
\text { Dinh }\end{array}$ & June 2002 \\
\hline
\end{tabular}

